\title{
The Effect of Intensive Keramba on the Presence of Parasite Organisms in Rivers of Lingsar Area
}

\author{
Supriadi" and Maratun Janah \\ Faculty of Veterinary Medicine, University of West Nusa Tenggara, Mataram \\ Jl. Tawak-tawak Karang Sukun, Mataram, Tel. +62-370-636875 \\ Author correspondency*: \\ supriadi@yahoo.co.id
}

\begin{abstract}
The application of intensive keramba in rivers could affect the presence of parasite organisms throughout the river downstream. The aims of this research are to find out the diversity of parasite species and the effect of intensive aquaculture method developed by the community on the presence of various parasitic organisms, particularly in the downstream area. A total of 65 Tilapia fish samples ( $O$. niloticus) that was collected from 3 areas (15 samples from upstream, 25 samples in keramba and 25 samples from downstream areas) have been examined in the laboratory of Faculty of Mathematic and Natural Science, University of Mataram. Methods employed to identify parasites that infected fish samples are native method and flotation method. This research has identified 7 species of parasites which were divided into 2 groups: ectoparasites (Trichodina sp., Amylodinium sp., Oogonium sp., Dactylogirus sp., Trematode) and endoparasites (Entamoeba sp. dan Camallanus sp.). Diversity index calculation indicated that parasite organisms in upstream area were lower in number than that in the downstream and intensive karamba area $\left(H^{\prime}=(0,825 ; 1,596\right.$ dan 1.324 respectively). These data has showed there was a difference in species diversity and evenness index of parasite organisms in the upstream, downstream and intensive keramba area. In conclusion, there was significant influence of the application of intensive keramba on the appearance of various parasite organisms that could affect the sustainability of fish aquaculture.
\end{abstract}

Keywords: Intensive keramba, parasites organism and diversity index

\section{Introduction}

Fishery products have become the highest animal protein sources demanded in Indonesia with the consumption rate of these products has reached $30.4 \mathrm{~kg} /$ capita/year or $72 \%$ of animal protein consumption/capita/year (Anonima, 2013). Although the prospect of fishery sector development in Indonesia is high, especially in freshwater fishery sector, there has been insignificant production growth in the last several years. This may be due to various factors such as fish farmers' low interest in the cultivation, capital shortage, lack of knowledge, stream water pollution and various diseases (parasites, bacteria and viruses) which result in considerable loss.

One of many factors that can lead to a decrease in the quality and quantity of fishery products is parasite infections (Akbar, 2011). The impact of the infection can be a decrease in fish population for consumption, reduction in fish weight, morphological changes and even in some cases; this can cause illness in humans (zoonoses parasite infection) (Herman and Chiodini, 2009; McCarthy and Moore, 2000; Punyagupta et al., 1990). Declining fish population triggered by the degraded water quality in the cultivation sites is a direct aspect and unsettling condition for fish farmers (Bell and Burt, 1991). The presence of parasite organisms such as Digenea worms, Cestodes, Nematodes, Acantochepals and several ectoparasites from Copepode group greatly affects aquaculture activities (Kennedy, 1990; Lawton, 1989). According to Salgado-Maladona et al., 2005, the presence of parasites in freshwater fish populations are often linked to the quality of the aquatic environment. Moreover, environmental degradation is also often associated with a greater diversity of parasitic infections (Chubb, 1963). Dominance and density of infection of pathogenic organisms is often directly proportional to the environmental degradation (Quiroz-Martı'nez and Salgado-Maldonado, 2013).

One method of fish farming that is directly cultivated in the river is intensive keramba method. This method is very simple and easy, even though its feasibility has not been tested ecologically. To anticipate the possibility of eutrophication impact in the downstream and the risk of pathogenic organism growth, it is necessary to conduct this research to study the diversity of parasitic organism caused by the application of intensive keramba method as well as the method's impact on the presence of parasitic organisms particularly in the downstream area.

\section{Research Methods}

This research was conducted from July to August 2014. Sampling was carried out in the river which became the center of cultivation, located in Lingsar sub-district, West Lombok Regency. Fish sample examination was performed in the Laboratory of Biology, Faculty of Mathemathics and Natural Science, University of Mataram.

Parameters to be measured and examined in this research were the species and the diversity of parasitic organisms, species eveness index and the frequency of 
parasitic organisms' presence in wild fish as well as in keramba-farmed fish.

Fish collection was performed in sampling spots which were purpospreively determined and refered to the actual condition on field. The fish were collected utilizing fishnets and fishing rods. The fish net was thrown over 35 times to obtain as a minimum 10 fish on the certain spot. Farmed fish samples were acquired from the fish farmers on field.

Parasite specimens collected on field were preserved in $70 \%$ alcohol for further analysis in the Laboratory of the Faculty of Mathematics and Natural Science, University of Mataram. Fish organs, such as gill, digestive organs, and flesh (muscle around abdominal cavity), were examined for the presence of parasitic organisms. The obtained organisms were then transferred a physiological saline solution and were identified using a light microscope.

Staining on the parasitic specimen was necessary in order that the parasite organisms could be identified acurately. Infestation rate of the organisms from various samples was calculated by identifying the species discovered from the host tissue (gill, digestive track, flesh) and then counting the individual numbers. The species identification refered to identification books by Noble \& Noble (1989) \& Taylor et al., (2007). Endoparasite examination was performed utilizing saturated sugar method.

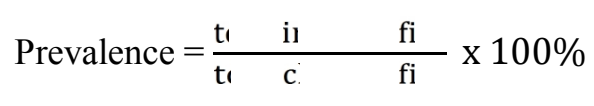

$$
\begin{gathered}
\text { Diversity index }=\log / \ln \frac{N_{i}}{N} \\
\text { Similarity Index }=\frac{d \quad i 1}{\operatorname{ll}\left(t_{i} \quad S \quad\right)} \times 100 \%
\end{gathered}
$$

(Choi et al., 2011; Kusmana, 1997)

Data obtained from this research were analysed descriptively by linking up the data and facts found on fields; whilst data interpretations were presented in the form of tables, figures and graphs. Subsequently, the conclusion was drawn deductively by describing the issues from general to specific points

\section{Results and Discussion}

\section{Results}

There were 25 fish samples that were collected randomly from several intensive Keramba in the river of Lingsar village. The examination results showed that there were various parasite infections. Parasites identified from this research were devided into ectoparasite and endoparasite group. The species that were included in ectoparasite group were Trichodina sp., Amylodinium sp., Oogonium $s p$., Dactylogirus sp and 1 species of Trematodes; while the endoparasites were Camallanus sp. dan Entamoeba sp (Figure 1).

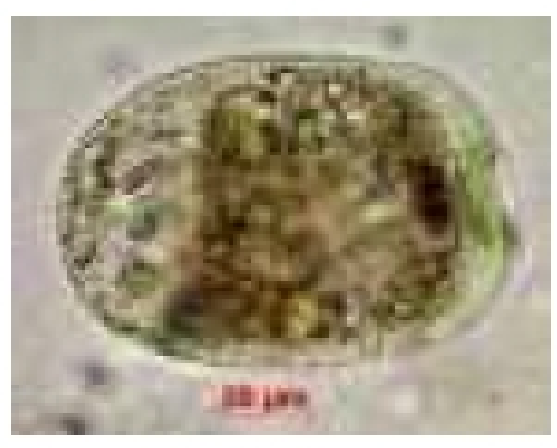

a

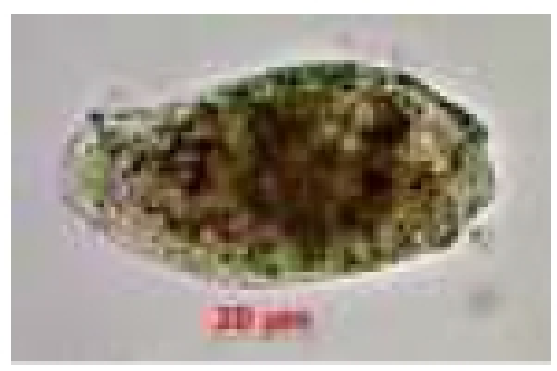

e

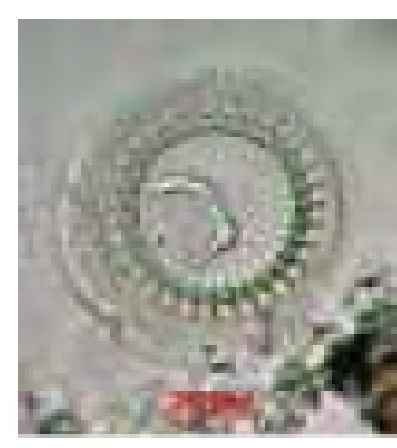

b

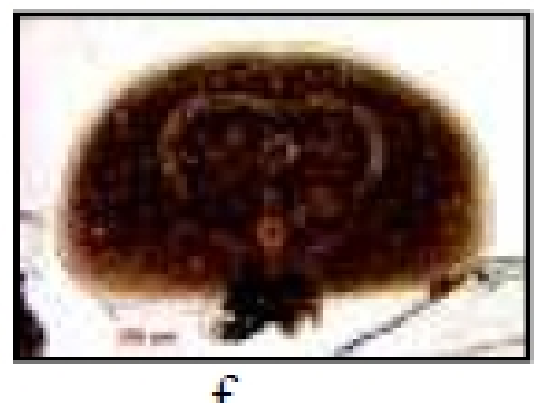

f

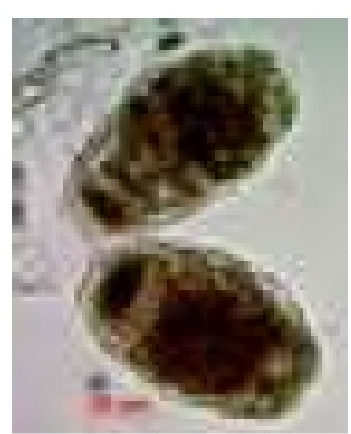

c

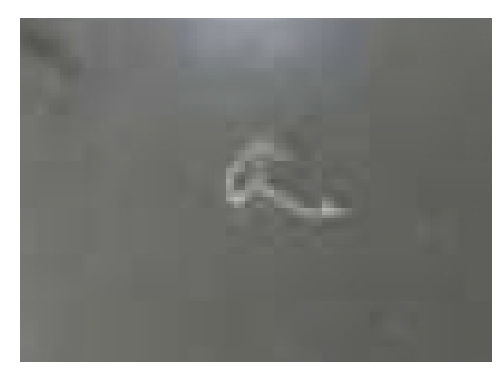

g

Figure 1. Parasites found in Tilapia fish from the river of Lingsar village. a. Amylodinium sp., b. Trichodina sp., c. Oogonium sp., d. Entamoeba sp., e. Dactylogirus sp., f. Trematoda dan g. Camallanus sp. 
The Shanon-Wiener diversity index of parasites in Tilapia fish (Oreochromis niloticus) from three sampling location (upstream, middle/keramba and downstream) were $0.8247,1.3244$ and 1.5962 respectively. These numbers demonstrated that the species diversity of parasites in the upstream, middle and downstream area were moderate. However, there were differences in the numbers and infection intensity in the upstream to downstream area; where the frequency of infection in the upstream was very low in contrast to the very high infection frequency in the middle and downstream area.

Table 1. Comparison of Diversity Index Value (H'), Species Eveness (E) and Frequency (F) of Parasite organisms Presence in three sampling location.

\begin{tabular}{lllll}
\hline No. & Sampling Location & H' & E & F (\%) \\
\hline 1 & River upstream & 0.8247 & 0.4238 & 46.7 \\
2 & Intensive Keramba & 1.3244 & 0.6806 & 96.0 \\
3 & River downstream & 1.5962 & 0.8203 & 92.0 \\
\hline
\end{tabular}

The calculation results of the presence frequency of parasites organisms illustrate that the infection frequency tend to get higher in the downstream area. In the river upstream, the infection frequency was $46.7 \%$, in the intensive keramba was $96.0 \%$ and in the downstream was $92.0 \%$. According to the graph in figure 2 , a number of 7 parasite species infected fish were collected in the river downstream and in the intensive keramba owned by the community. On the other hand, only 3 species of ectoparasite were discovered infecting the fish collected from the upstream. Further, it can be explained that the dominant species infecting the fish was Trichodina sp. This species was found in all sample groups. What is more, the species of Amylodinium sp and Oodinium sp. were also had the same presence frequency as Trichodina sp. However, the intensity (density) of infection of the two species were lower compared to that of Trichodina sp (Figure 2).

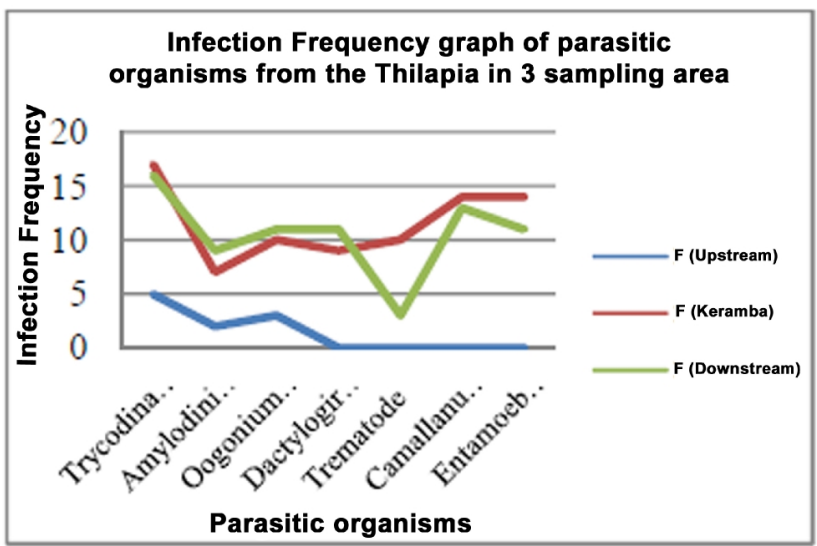

Figure 2. Comparison of the Infection Frequency in Tilapia Fish from 3 three Sampling Location.

Data of parasite species diversity index from three location show that there was a significant difference. In the upstream area, the parasite species diversity index is low which counted at 0.8247 . Meanwhile, the parasite diversity index in the intensive keramba area and downstream area were counted at 1.3244 and 1.5962 respectively. Based on these values of Shannon-Wiener diversity index, it can be stated that the upstream area has lower parasite species diversity, while the keramba area and downstream area have moderate diversity.
Evenness index values of the parasite species show increasing trends toward the downstream area. In the upstream area, only 3 species of parasites were discovered, whereas in keramba site and downstream area, 7 species of parasites were identified. However, there was similar data pattern i.e all parasite species found in the upstream were also found in Tilapia fish collected from keramba site and the downstream.

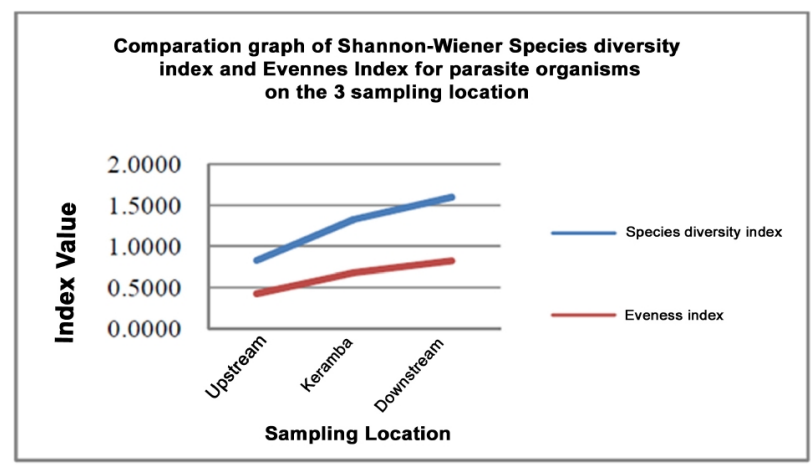

Figure 3. Comparation graph of Shannon-Wiener species diversity index and species Evennes Index for parasite organisms on the 3 (three) sampling location.

The number of parasite species identified in each sampling location illustrates the drastic increase from upstream ( 3 species) toward downstream area ( 7 species). The main difference is the level of parasites density. Even though there were only 7 species discovered in keramba site and downstream area, the parasites individual number than infects the keramba-cultured fish was higher (Figure $3)$.

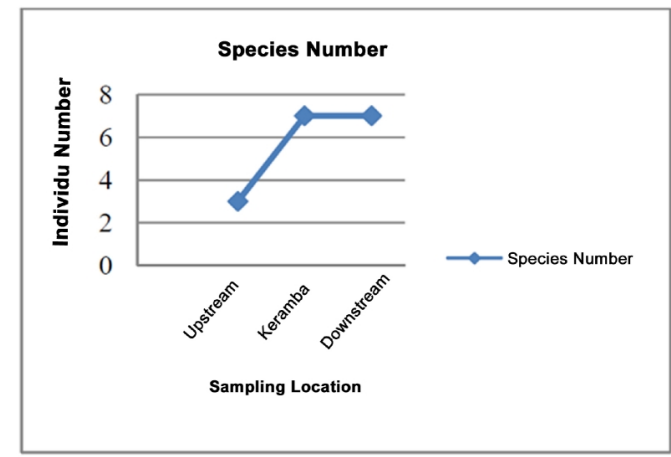

Figure 4. Graph for difference in species number of parasites that infect Tilapia fish in three different sampling location. 


\section{Discussion}

Based on the analysis and laboratory examination results, as many as 7 species of parasites infected Tilapia fish caught in the upstream, keramba site and the downstream. The species include ectoparasite Trichodina sp., Amylodinium sp., Oogonium sp., Dactylogirus sp, 1 species of Trematode, and 2 endoparasites (Camallanus sp. and Entamoeba sp (Figure 1)).

Dominant species found in this study is Trichodina sp. which was discovered in all sampling locations. According to Eronimo et al., (2012), these parasite species are common ectoparasites that infect Tilapia fish farmed in freshwater. Further explained is that this parasite infection mostly happen in gill and skin area, which reduce the immunity system of the infected fish (Martin, 2012). Amylodinium sp. and Gymnodinium sp. were two other ectoparasites that were discovered in all sampling locations, although with lower individual density. This may be due to the two species competition with Trichodina sp.

Other than protozoa, this research also found Trematode worm (ectoparasite) on the fish gill and was identified as Dactylogyrus sp. This species is mostly discovered in the fish collected from the downstream and keramba sites. This Trematode worm is pathogenic and often become the cause of fish mortality in several fish farming sites. By infesting the gill of freshwater fish (Tilapia), this parasite infection would escalate the heart rate to pump up the blood to the gill and increase mucus production, causing the difficulty in taking in oxygen from water (Eva, 2007). Beside Dactylogyrus sp., there was also another unidentified Treamatod worm. However, this species is rarely found infecting the sampled Tilapia fish.

Two endoparasites species identified in this study, i.e Camallanus sp. and Entamoeba sp., are Nematode worms that were mostly found in fish intestine. Kabata (1985) also explained that these worms often infect the intestine of freshwater fish. Furthermore, these parasite species are often discovered infecting freshwater fish in aquariums. These Nematodes infection is easily spreading as the worms do not require intermediate hosts in their life cycles (Untergasser, 1989). Besides, the worms infection is very damaging to their hosts as the worm can wound the host's intestine by biting the intestine wall using the worm's bucal capsules. This research identified Camallanus sp. With the length of $10-15 \mathrm{~cm}$. This discovery is supported by research results of Buchmann \& Bresciani (2001) and Arie (2008) who found that the female worms could reach the length of $22 \mathrm{~cm}$ while the male ones could have the length of $11 \mathrm{~cm}$.

Analysis results of species diversity showed that there was significant difference in species diversity index from the upstream to downstream. Species diversity index values for upstream, keramba, and downstream area are $0.8247,1.3244$ and1.5962 respectively. These data display a pattern that the number and density of parasite infection were changing from the upstream to downstream. In the upstream, parasite infection in Tilapia fish was very low with only a total of 3 parasite infection and low parasite density.

Increasing individual number and species of parasites infecting the fish from the upstream to downstream can be triggered by various biotic and abiotic factors. Biotic factors include organisms carrying parasites (hosts) and abiotic factors include aquatic environmental pollution as a result of human activities which produce wastes or change the condition of aquatic environment. As stated by Quiroz-Marti'nez and Salgado-Maldonado (2013), intensive keramba culture would increase the risk of change in various environmental condition as a result of feeding residue pollution. It can be further explained that feeding remnants from the intensive keramba farming can pollute the aquatic environment in the form of changing water $\mathrm{pH}$, eutrophication and decreasing water clarity. However, these factors are not the only factors that pollute the aquatic environment.

Species evenness index on the three sampling locations showed that there was also a significant difference. The values of species evenness index for upstream area, keramba sites, and downstream area are $0.4238,0.6806$ and 0.8203 respectively. The values illustrated that parasites presence in the upstream was rare in contrast to the higher species and individual number of parasites in the intensive keramba site and downstream area. This means that fish farming which employing intensive keramba method in the river has a significant effect on the presence of various parasite species. The high parasite infection on keramba-cultured fish is a result of high density of the fish farmed in the intensive keramba. In contrast, fish density outside keramba was very low. The dense environment inside keramba has made it possible for the parasite to easily transmit from one individual fish to another. This is also supported by the parasite density data observed in downstream area. Although the species number of parasite identified in the downstream was the same as those found in keramba, the density of the individual parasite found in fish caught from the downstream was lower than those infecting keramba-fish. Furthermore, the sparse distribution of fish in the downstream contributed to the lower possibility of parasite organism to transmit between individual or species of fish.

Data from this research has shown the effect of intensive keramba culture on the presence of parasite organisms in farmed-fish and wild fish. However, it is also important to conduct a research in different season and perform measurement of other factors such as the effect of habitation in the vicinity of river and water pollutant from the surrounding rice field. Therefore, recommendation for the application feasibility of intensive keramba system in rivers can be comprehensively established.

\section{Conclusion}

From this research, it can be concluded that parasite species diversity of fish in downstream area and intensive 
keramba sites were higher than that in the upstream; with the values of species diversity index was 0.8247 in the upstream, 1.3244 in keramba sites and 1.5962 in the downstream. In other words, fish culture employing intensive keramba system has a significant effect on the presence of various parasite organism on fish in the downstream area.

\section{References}

Akbar, J. 2011. Identifikasi Parasit Pada Ikan Betok (Anabas testudieus). Bioscientiae. Volume 8, Nomor 2, Juli 2011, Page 36-45.

Anonima, 2013. Bisnis Ikan di Indonesia Timur: Tantangan dan Potensinya. $\quad \mathrm{http}: / /$ nyataindonesiaku.com/bisnis-ikan-diindonesia-timur-tantangan-dan-potensinya./Akses 29/11/2013. 21.30 WITA.

Arie, U. 2001. Pembenihan dan Pembesaran Nila Gift. Penebar Swadaya. Jakarta.

Bell, G., and A. Burt. 1991. The comparative biology of parasite Species diversity: internal helminths of Freshwater fish. Journal of Animal Ecology. (1991), 60, 1047-1063.

Buchmann K \& Bresciani J. 2001. An Introduction to Parasitic Diseases of Freshwater Trout. Denmark: DSR Publisher.

Choi, S. H., J. Kim, J. OK- Jo, Min K. Cho, H. S. Yu, H. J. Cha and M. S. Ock. 2011. Anisakis simplex Larvae: Infection Status in Marine Fish and Cephalopods Purchased from the Cooperative Fish Market in Busan, Korea. Korean J Parasitol. Vol. 49: No. 1: 39-44.

Chubb, J.C. 1963. On the characterization of the parasite fauna of the fish of Llyn Tegid. Proc Zool Soc Lond. 141:609-621.

Eva.G. 2007. Ectoparasites and Endoparasites among Oreochormis Niloticus (tilapia). Liceo Journal of Higher Education Research.

Herman, J. S and P. L, Chiodini. 2009. Gnathostomiasis, another emerging imported disease. Clin Microbiol Rev. 22: 484-492.

Irianto. A. 2005. Patologi Ikan Teleostei. Gadjah Mada University Press. Yogyakarta.
Jeronimo, G.T., N. da C. Marchiori1, S. B. de Pádua, J. D. Neto, F. Pilarski, M. M. Ishikawa, and M. L Martins. 2012. Trichodina colisae (Ciliophora: Trichodinidae): new parasite records for two freshwater fish species farmed in Brazil. Rev. Bras. Parasitol. Vet., Jaboticabal, v. 21, n. 4, p. 366-371.

Kabata, Z. 1985. Parasites and Diseases of Fish Cultured in the Tropics. Taylor and Francis. London. 318 pp.

Kennedy, C.R. 1990. Helminth communities in freshwater fish: structured communities or stochastic assemblages? Parasite Communities: Patterns and Processes (Ed. by G.W. Esch, A.O. Bush \& J.M. Aho), pp. 131-156. Chapman and Hall, London.

Martin, ML, Marchiori, N., Roumbedakis, K. and Lami, F. Trichodina nobilis Chen, 1963 and Trichodina reticulata Hirschmann et Partsch, 1955 from ornamental freshwater fishes in Brazil. Braz. J. Biol. vol. 72, no. 2, p. 281-286

McCarthy, J and T. A. Moore. 2000. Emerging helminth zoonoses. Int J Parasitol. 30: 1351-1360.

Noble, E.R \& Noble G.A. 1989. Parasitologi Biologi Parasit Hewan. Edisi ke-5.Wardiarto, penerjemah; Soeripto N. editor. Yogyakarta. Gadjah Mada University Press. Translation from: Parasitology: The Biology of Animal Parasites 5th edition.

Punyagupta, S., T. Bunnag and P. Juttijudata. 1990. Eosinophilic meningitis in Thailand. Clinical and epidemiological characteristics of 162 patients with myeloencephalitis probably caused by Gnathostoma spinigerum. J Neurol Sci. 96: 241-256.

Purbomartono. C, Isnaetin. M dan Suwarsito 2010. Ektoparasit Pada Benih Ikan Gurami (Osphronemus gouramy, Lac) di Unit Pembenihan Rakyat (UPR) Beji dan Sidabowa, Kabupaten Banyumas. Sains Aqutic Journal.

Quiroz-Martı'nez, B., and G. Salgado-Maldonado. 2013. Patterns of Distribution of the Helminth Parasites of Freshwater Fishes of Mexico. PLoS ONE 8(1):

Sukardi, M.F, 2002. Peningkatan Teknologi Budidaya Perikanan. Jurnal lktiologi Indonesia Vol.2, No. 2.

Taylor, M. A., R. L. Coop, and R. L. Wall. 2007. Veterinary Parasitology 3th Edition. Blackwell Publishing; Victoria Australia.

Utergasser, D. 1989. Handbook and Diseases. T.F.H Publication Inc. Translated by Howard H. Hirschron. Neptune City. United States. $159 \mathrm{~h}$ 
